\title{
Changing Landscapes Under Roman Impact: Interdisciplinary Research in Northern Etruria
}

\author{
Günther Schörner
}

In the last 30 years, studies with a focus on landscape archaeology were mushrooming and landscape became one of the determining concepts in archaeological research. A quick search in the bibliographical database Dyabola revealed unambiguous results: ${ }^{2}$ While between 1956 and 1999 only 289 studies in the field of Classical Archaeology and Ancient History had the word "landscape" as part of their title it was used by already 458 in only ten years from 2000 till 2009. This already impressive number is nearly doubled by the 883 landscape titles in the last decade (2010-2019).

Although landscape archaeology is one of the most productive fields of archaeology, there is no strict definition of what landscape archaeological studies are or should be. ${ }^{3}$ The recently proposed description of a popular German introduction to landscape archaeology defines it as follows: "Landschaftsarchäologie betreibt der, der sich mit landschaftsarchäologischen Fragestellungen auseinandersetzt - also mit noch zu beschreibenden Methoden Erkenntnisse zur Kulturlandschaftsgenese gewinnt". This definition shifts the problem towards the methods applied and to geography and social sciences. ${ }^{4}$ Although such a pragmatic and narrow definition has its advantages, most

1 I thank the organizers of the conference "The Impact of Empire on Roman Landscapes" for inviting me to this most interesting and productive event. I thank all the discussants in Mayence for useful suggestions and thought-provoking questions. Finally, I thank Jonas Breßler for editing my English text.

2 http://www.db.dyabola.de; accessed on July 11, 2020. See also the compilation in B. David and J. Thomas, 'Landscape archaeology: introduction', in B. David and J. Thomas (eds.), Handbook of Landscape Archaeology (Walnut Creek [CA] 2008), 29, tab. 1.1 (citations in current archaeological journals in the UK and the USA). The term "landscape archaeology" appears for the first time in the title of M. Aston and T. Rowley, Landscape Archaeology: An Introduction to Fieldwork Techniques on Post-Roman Landscapes (London 1974).

3 For example K.F. Anschuetz, R.H. Wilshusen and C.L. Scheick, 'An archaeology of landscapes: perspectives and directions', Journal of Archaeological Research 9 (2001), 158.

4 P. Haupt, Landschaftsarchäologie. Eine Einführung (Darmstadt 2012), 11. 
researchers see landscape as the crucial term insofar as landscape emphasizes different aspects of the environment in a general sense. ${ }^{5}$ As B. Bender has shown, landscape is used in various terminological combinations and various meanings. These include landscape as solid geology (karst landscape), landscape as land form (desert landscape), landscape as land-use (arable landscape), landscapes of settlement (villa landscape). ${ }^{6}$ It is, however, noticeable that most of the landscape concepts developed refer to a nature-culturecontinuum and make the dynamic interactions of humans with their physical setting subject of discussion. ${ }^{7}$

The aim of most studies is to investigate and interpret the ways in which different historic peoples shaped the environment, and the ways, in which these peoples were influenced, inspired, or confined by the environment. Thereby, the recognition that the natural setting - the landscape - played an active role was particularly innovative. In an already classical statement A.B. Knapp and W. Ashmore put it as follows: "That what was once theorized as a passive backdrop or forcible determinant of culture is now seen as an active and far more complex entity in relation to human lives."

Although the recognition of the mutual influence and interdependency between humans and environment is highly symptomatic for landscape archaeology, there are other features which can be seen as characteristic for

5 Here lays one of the differences between Anglo-American (including Dutch) landscape archaeology and Central European (mostly German and Austrian) Landschaftsarchäologie where post-processual approaches were never intensively applied and the constructed dimension of landscape dominates, see below. That comparison is simplified as it disregards the differences between landscape archaeology in the UK and that in the US and as it omits completely French and Italian versions of archéologie du paysage and archeologia del paesaggio; for a history of American landscape archaeology: T.C. Patterson, "The history of landscape archaeology in the Americas', in B. David and J. Thomas (eds.), Handbook of Landscape Archaeology (Walnut Creek [CA] 2008), 77-84; for archaeologia del paesaggio see M. Bernardi (ed.), Archeologia del paesaggio (Florence 1992); F. Cambi, Archeologia dei paesaggi antichi:fonti e diagnostica (Rome 2003); for archéologie du paysage see P. Leveau, 'L'archéologie du paysage et l'antiquité classique', Agri centuriati. An International Journal of Landscape Archaeology 2 (2005), 9-24; G. Chouquer, Quels scénarios pour l'histoire du paysage? Orientations de recherche pour l'archéogéographie (Coimbra and Porto 2007).

6 B. Bender, 'Time and landscape', Current Anthropology 43 (2002), 103.

7 Fundamental: D.E. Cosgrove, 'Prospect, perspective and the evolution of the landscape idea', Transactions of the Institute of British Geographers 10 (1985), 45-62; Anschuetz, Wilshusen and Scheick 2001, op. cit. (n. 2) 158; with another conception: K. Walsh, 'Mediterranean landscape archaeology: marginality and the culture-nature 'divide", Landscape Research 33 (2008), $547-564$.

8 A.B. Knapp and W. Ashmore, 'Archaeological landscapes: Constructed, conceptualized, ideational', in A.B. Knapp and W. Ashmore (eds.), Archaeologies of Landscape: Contemporary perspectives (Malden [MA] 1999), 2. 
the landscape paradigm: Landscape is primarily a spatial category insofar as a landscape occupies a physical space but it is not identical with neutral Cartesian space or the natural or built-up environment. ${ }^{9}$ The decisive concept is place since places are meaningful human products which are created out of spaces through daily routines and events, but also ideas, and systems of values and beliefs. Thus, for example, any spring can be given specific meaning and become a place when it is the daily visited water source for my household, when it is the place I saw my spouse for the first time or when I believe it is the dwelling place of nymphs. In that sense landscape is made of places and is itself a place. Landscape is not only a product of human activities and perceptions but also their stage. ${ }^{10}$ That implies a necessary shift from the study of single sites to a much broader regional approach. In his seminal work on The Archaeology of Place L. Binford stated the importance of site-patterning in both within-place and between-place contexts. ${ }^{11}$ In consequence, landscape archaeology indicates (and requires) non-site and off-site approaches because traditionally recognized site types have not longer be seen as reliable units of spatial analysis although landscapes do not need to have a definite, exact dimension. ${ }^{12} \mathrm{H}$. Chapman sees "an approach where the unit is the artefact rather than the site" more appropriate for landscape archaeology since it "recognizes that many of the material consequences of human behavior are ephemeral and will not conform to standard definition of sites."13 Therefore

For the relationship of space and place see $e . g$. Anschuetz, Wilshusen and Scheick 2001, op. cit. (n. 2), 160-161. For a more in-depth treatment: M. Hunziker, M. Buchecker and T. Hartig, 'Space and place - two aspects of the human-landscape relationship', in F. Kienast, O. Wildi and S. Ghosh (eds.), A Changing World: Challenges for Landscape Research (Dordrecht 2007), 47-62; E.S. Casey, 'Place in landscape archaeology: a western philosophical treatment', in B. David and J. Thomas (eds.), Handbook of Landscape Archaeology (Walnut Creek [CA] 2008), 44-50; fundamental: Y. Tuan, Space and Place: The Perspective of Experience (Minneapolis [MI] 1977).

10 For the centrality of the concept 'place': J. Thomas, 'Archaeologies of place and landscape', in I. Hodder (ed.), Archaeological Theory Today (Cambridge 20o1), 165-186; Anschuetz, Wilshusen and Scheick 2001, op. cit. (n. 2), 161; J. Kantner, 'The archaeology of regions: from discrete analytical toolkit to ubiquitous spatial perspective',Journal of Archaeological Research 16 (2008), 58.

11 L. Binford, 'The archaeology of place', Journal of Anthropological Archaeology 1 (1982), 6.

12 L. Wandsnider, 'Regional scale processes and archaeological landscape units', in A.F. Ramenofsky and A. Steffen (eds.), Unit Issues in Archaeology: Measuring Time, Space, and Material (Salt Lake City [UT] 1998), 87-102, esp. 94; Anschuetz, Wilshusen and Scheick 2001, op. cit. (n. 2), 171-172; M.P. Heilen, An Archaeological Theory of Landscapes (Ann Arbor [MI] 2005), 113-119.

13 H. Chapman, Landscape Archaeology and GIS (Stroud 2006), 11. He is cited by A.-J. Wijnstok, 'Who would have GISsed'? Influences on the interpretation of landscape in 
the site-less or off-site survey is one of the particularly suitable methods for landscape archaeology. ${ }^{14}$ Furthermore all methods that are apt to investigate larger areas, not only sites, like aerial photography, LIDAR scanning, and geophysical prospection methods, are widely used in landscape archaeological projects. ${ }^{15}$ Especially the use of GeoInformationScience which enabled the establishment of a GeoInformationSystem and by that to store, capture, analyze and visualize spatially referenced data is indispensable and allows to better understand past behavior. ${ }^{16}$ The opposite, however, is not necessarily the case: the application of these methods does not make all archaeological projects with a wider spatial focus, like regional settlement pattern studies, become landscape archaeology projects.

From the outset of landscape studies in a narrower sense, landscape has been seen as a "palimpsest" because the landscape is like "a document that has been written on and erased over and over again."17 Thus landscapes represent not only multiple places, but also multiple times. That palimpsest nature of the landscape allows for the analytical investigation of single phases by

landscape archaeology', in D.C.M. Raemaekers (ed.), Past Landscapes. Questioning Function and Meaning (Groningen 2016), 2.

14 Recent bibliography: T. de Haas, 'Beyond dots on the map: intensive survey data and the interpretation of small sites and off-site distributions', in P. Attema and G. Schörner (eds.) Comparative Issues in the Archaeology of the Roman Rural Landscape. Site Classification between Survey, Excavation and Historical Categories (Portsmouth [RI] 2012), 55-79; H. Forbes, 'Off-site scatters and the manuring hypothesis in Greek survey archaeology: an ethnographic approach', Hesperia 82 (2013), 551-594; G. Schörner, 'Der Survey am Sinektepe: Methoden und erste Ergebnisse', in B. Dreyer and S. Aybek (eds.), Die Surveys im Hermos- und Kaystrostal und die Grabungen an den Thermen von Metropolis (Ionien) sowie am Stadion von Magnesia am Mäander (Münster 2014), 38-97.

15 Short overviews on methods: Kantner 2008, op. cit. (n. 9), 47-55; Haupt 2012, op. cit. (n. 3), 28-87; M. Doneus, Die hinterlassene Landschaft - Prospektion und Interpretation in der Landschaftsarchäologie (Vienna 2013), 135-274.

16 The bibliography is ample. Fundamental are: Chapman 20o6, op. cit. (n. 12); J. Conolly and M. Lake, Geographical Information Systems in Archaeology (Cambridge and New York 2006); J. Conolly, 'Geographical Information Systems and landscape archaeology', in B. David and J. Thomas (eds.), Handbook of Landscape Archaeology (Walnut Creek [CA] 2008), 583-595; history of GIS in archaeology: P. Verhagen, 'Spatial analysis in archaeology: moving into new territories', in C. Siart, M. Forbriger and O. Bubenzer (eds.), Digital Geoarchaeology. New Techniques for Interdisciplinary Human-Environmental Research (Heidelberg 2018), 11-25; an instructive comparison of pre-GIS and GIS driven interpretations in the archaeological research of a particular landscape: Wijnstok 2016, op. cit. (n. 12), 1-6.

17 O.G.S. Crawford, Archaeology in the Field (London 1953), 51. The palimpsest metaphor is commonplace in landscape archaeological studies, see as one of the latest examples S. Turner, L.-M. Shillito and F. Carrer, 'Landscape archaeology', in P. Howard et al. (eds.), The Routledge Companion to Landscape Studies (London and New York 2018), 156. 
disentangling the traces and "scripts" piled up in the course of time. ${ }^{18}$ These time slices of landscapes are created by day-to-day routines like ploughing as well as by one-time events like road construction or land distribution. In order to express this close connection, the term "temporality of landscape" has been coined. ${ }^{19}$ This time-related quality is especially relevant for the present workshop and gives significance to the question of a landscape being 'Roman'. Therefore, landscapes embody not only continuity and continuous usage but also change and transformation. ${ }^{20}$ That close relationship between landscape and time is not neutral with respect to the perceptive meaning of landscape. It has to be noted that time manifests itself in different ways as the notion of time in landscapes ranges from timeless landscapes to historical landscapes with more or less time-depth. ${ }^{21}$

The word landscape originally belonged to art history since it was a term for the view on natural scenery or its painted representation. ${ }^{22}$ Considering this etymology, landscape has always had a strong perceptual aspect, which is evident in the definition of landscape given by G. Fairclough: "Environment changes into landscape in the eyes of the beholder who constructs landscape from the material environment."23 After the change from processual archaeology to post-processual archaeology, the phenomenology of landscapes became the fastest growing direction in landscape archaeology. ${ }^{24}$ As this approach generally aims to perceive the landscape as past people have perceived it and is based on the perception of those people, the prime example were the landscapes of Neolithic megaliths in the British Isles. Is has been - quite

18 Knapp, Ashmore 1999, op. cit. (n. 7), 18.

19 For example T. Ingold, 'The temporality of the landscape', WorldA 25 (1993), 152-174.

20 See the title: N. Christie (ed.), Landscapes of Change: Rural Evolutions in Late Antiquity and the Early Middle Ages (Aldershot 2004).

21 Bender 2002, op. cit. (n. 5), 103-112.

22 F. Förster et. al., 'What is landscape? Towards a common concept within an interdisciplinary research environment', eTopoi. Journal for Ancient Studies, special issue 3 (2012), 169-170.

23 G. Fairclough, 'The long chain: archaeology historical landscape characterization and time depth in landscape', in G. Fairclough et al. (eds.), The Heritage Reader (London and New York 2008), 409; see also K. Karro, M. Mägi and H. Palang, 'Studying past landscapes: lived, reconstructed and animated', Living Reviews in Landscape Research 8 (2014), 5 .

24 C. Tilley, A Phenomenology of Landscape (Oxford 1994); S. Hamilton and R. Whitehouse, 'Phenomenology in practice: towards a methodology for a "subjective" approach', European Journal of Archaeology 9 (2006), 31-71; C. Tilley, "The neolithic sensory revolution: monumentality and the experience of landscape', Proceedings of the British Academy 144 (2007), 329-45; M.H. Johnson, 'Phenomenological approaches in landscape archaeology', Annual Review of Anthropology 41 (2012), 269-284; J. Wylie, 'Landscape and phenomenology', in Howard et al. 2018, op. cit. (n. 16), 127-138. 
rightly - criticized that it is not possible to understand what humans several thousand years ago thought and how they perceived and experienced their environments. ${ }^{25}$ It is important to stress that Roman archaeologists and Classicists are in a much better situation when they investigate Roman landscapes since - in contrast to prehistory - written evidence can be used which provides emic statements on how the landscape has be seen and valued. ${ }^{26}$

The post-processual phenomenological approach entailed two aspects that are important for landscape studies in general: it highlighted the bodily experience of landscapes, which is the theoretical basis for the development of analyses like least path analysis or view-shed analyses, and emphasised landscapes in order to replace the neutral Cartesian space by bodily experienced space. ${ }^{27}$ Further, it helped to understand that the perception of individuals is central for the interpretation, the generation and the attribution of meaning to landscapes - the most evident examples for that processes is the research field concerning "landscapes of memory". ${ }^{28}$

Landscape is a transdisciplinary concept since it falls along the natureculture-continuum. ${ }^{29}$ In consequence, landscape archaeology absorbs influences from the humanities (e. g. history), but also from the natural sciences (especially various earth sciences) and social sciences (primarily anthropology and geography). Therefore landscape archaeology has no single valid method and approach. This can be seen as weakness when landscape archaeology is considered "a fashionable umbrella", "an empty shell containing everything yet nothing" or - still worse - a "junk drawer because of the lack of directed

25 J. Brück, 'Experiencing the past? The development of phenomenological archaeology in British prehistory', Archaeological Dialogues 12 (2005), 45-72; A. Fleming, 'Post-processual landscape archaeology: a critique', CambrAJ 16 (2006), 267-280; J.C. Barrett and I. Ko, 'A phenomenology of landscape: a crisis in British landscape archaeology?', Journal of Social Archaeology 9 (2009), 275-294. Meanwhile an 'enhanced version' of the phenomenological approach has been developed: D. Crystal, 'Postphenomenology and archaeology: towards a temporal methodology', Time and Mind. The Journal of Archaeology, Consciousness and Culture 11 (2018), 297-304.

26 For example: G. Shipley and J. Salmon (eds.), Human Landscapes in Classical AntiquityEnvironment and Culture (London and New York 1996); D. Spencer, Roman Landscape: Culture and Identity (Cambridge 2013). Much interdisciplinary work is still to be done.

27 C. Tilley, 'Mind and body in landscape research', CambrAJ14(2004), 77-80; P. Rainbird, 'The body and the senses: implications for landscape archaeology', in B. David and J. Thomas (eds.), Handbook of Landscape Archaeology (Walnut Creek [CA] 2008), 263-270.

28 Important case studies: S.E. Alcock, Archaeologies of the Greek Past: Landscapes, Monuments, and Memories (Cambridge 2002); summarizing: R.M. van Dyke, 'Archaeology and social memory', Annual Review of Anthropology 48 (2019), 207-225, especially $213-214$.

See above fn. 6. 
methods". ${ }^{30}$ In total, that conceptual ambiguity, however, is more often deemed useful, ${ }^{31}$ as the openness of the landscape paradigm allows to adopt different theoretical perceptions. The better understanding of a specific landscape may serve as a superordinate aim for different approaches like settlement archaeology. ${ }^{32}$ In general, landscape archaeology has to be seen as a field where scientific disputes may be bridged. ${ }^{33}$

\section{Research in Northern Etruria: The Vienna Orme and Pesa} Valley Project

In the first session of the conference on the impact of Roman rule on landscape, a decisively landscape archaeological approach is chosen. This case study is one of my own projects, the Vienna Orme and Pesa Valley Project $(V O P P)$, augmented by the results of a further fieldwork project in the neighboring Chianti region.

The research area of VOPP is the territory along the valleys of the Orme and Pesa, two tributaries of the Arno. The region lies at the junction between the surroundings of Empoli in the Arno plain and the more hilly inland territory to the south. As it is typical for landscape archaeological projects, a collaborative and holistic approach is pursued, which combines a broad range of methods in a multi-stage and multi-scalar fieldwork scheme. Data are systematically collected from a diversity of sources, namely excavations centred on one especially promising site, Molino San Vincenzo. These excavations were supplemented by a wide range of scientific analyses like geophysical prospections (geomagnetics and georadar), geoarchaeological investigations and systematic on-site surveys at Molino San Vincenzo and at various other places at different distances from the most important Roman town of that region, present-day Empoli. This more site-oriented research is embedded in a broader regional context, provided by off-site surveys of the valleys of Pesa and Orme, and larger scale agricultural modelling, geoarchaeological studies and remote sensing. ${ }^{34}$

30 All citations: S.A. Kowalewski, 'Regional settlement pattern studies', Journal of Archaeological Research 16 (2008), 253.

31 C. Gosden and L. Head, 'Landscape - a usefully ambiguous concept', Archaeology in Oceania 29 (1994), 113-116; W. Ashmore, 'Social archaeologies of landscape', in L. Meskell and R.W. Preucel (eds.), A Companion to Social Archaeology (Malden [MA] 2005), 255-256.

32 Anschuetz, Wilshusen and Scheick 2001, op. cit. (n. 2), 176.

33 For example: B. Tress et al., 'Bridging human and natural sciences in landscape research', Landscape and Urban Planning 57 (2001), 137-141.

34 For a more detailed presentation of the methods and results: G. Schörner (ed.), The Vienna and Orme and Pesa Valley Project. Proceedings of the International Workshop, Vienna 2018. Roman Rural Landscapes Monograph Series 1 (Vienna 2020). 
In historical perspective, one especially interesting period is the time from the more intense contact of local communities with the expanding political organisation of the Roman Empire starting in the Middle Republic to the developments in the Late Republic and to the conciliation with the Roman administration in the early Empire. In Italian literature, that period is designated as romanizzazione but often the term is taken not only chronologically but is understood as the cultural process of adopting Roman culture - similar to the English term romanization - leading to piena romanità. That approach is highly problematic - to say the least - but things are getting even worse since the two chronologically distinct phases are often connected with two distinct cultural entities, Etruscan and Roman, whereby culture often seems to be defined by ethnic identity. 35

Apart from the higher order concepts of romanizzazione or romanization some lower order questions remain useful in order to pragmatically describe landscapes in a provincial setting. As an example, the study of J.C. Edmondson may be cited, who investigated the impact of Rome on the rural landscapes in Hispania using the following terms for categorisation: ${ }^{36}$

- the pattern of rural settlement

- the nature of land use and agrarian exploitation

- the ways in which the landscape was perceived and thought about

Although they are providing functional steps, these questions miss the specific approach of landscape archaeology, which sees landscape not only as a purely constructed object of human actions but also as conceptualized and ideational. ${ }^{37}$

\section{In or Out: Centuriated Landscape and Lifestyle}

Next to the urban settlement of Empoli, the Roman name of which is still debated ${ }^{38}$ traces of a centuriatio have been identified. Even if a more refined investigation is pending there is no doubt that a centuriatio in the Middle Arno

35 Critics: G. Schörner, 'La Valdelsa tra romanizzazione e prima età imperiale II: Looking for romanization in the Valdelsa senese', in G. Baldini and P. Giroldini (eds.), Dalla Valdelsa al Conero. Ricerche di archeologia e topografia storica in ricordo di Giuliano de Marinis. Atti del Convegno internazionale di studi, Colle di Val d'Elsa, San Gimignano, Poggibonsi, 27-29 novembre 2015 (Florence 2016), 89-104.

36 J.C. Edmondson, 'Creating a provincial landscape: Roman imperialism and rural change in Lusitania', in J.G. Gorges and M. Salinas de Frías (eds.), Les Campagnes de Lusitanie romaine. Occupation du sol et habitats (Madrid 1994), 13-30.

37 See Knapp 1999, op. cit. (n. 7).

38 W. Maiuri, 'La città, il territorio, il porto: Empoli in età romana', Milliarium 6 (2006), 28-39. 
valley existed. It was probably established in the context of the founding of colonies in Northern Etruria in the second half of the 1st century BCE together with the centuriatio of the lower Elsa Valley or the Arno plain near Florence as attested in the liber Coloniarum..$^{39}$

The centuriatio signifies a radical change of the rural world in the vicinity of towns that was connected with a profound re-organization of the agricultural production system, but it is still more than that because it relates not only to practicalities but also to the perception of landscape: It is obvious that the landscape can be conceptualized as centuriated or not centuriated in a very clear-cut dual system. ${ }^{40}$

It has rarely been asked what it meant to live in a centuriated landscape. That is a question which was investigated in the Vienna Orme and Pesa Valley Project by conducting targeted on-site surveys and geophysical prospections on various sites. Especially interesting were research on two sites, Molino San Vincenzo outside the centuriatio-grid and Il Cotone within the - or at least on the fringe of - the checkerboard of the limitation (fig. 9.1).

Molino San Vincenzo has been targeted by repeated on-site surveys, geophysical measurements and stratigraphical excavations. The research activities applied provide information on the complex history of the site that spans from an ancient settlement to a modern, intensively used agricultural area. ${ }^{41}$ Through those investigations, a quadrangular architectural complex erected on solid, multi-phased foundation walls has been discovered. At least two phases were observed at the site, the younger phase of which can be dated after the ist century BCE. Research undertaken in Il Cotone consisted of two on site surveys and geophysical measurements. Two small buildings have been detected there, whereby the densest concentration of sherds is located above structure B which only measures $10 \times 9.5 \mathrm{~m}^{42}$

Here, the focus shall be on the pottery found because by emphasizing the functional aspects of different shapes and types of ceramic vessels it is possible to understand the pottery as an expression of important social practices of

39 M. Ristori, 'Le divisioni agrarie romane nel Valdarno: la centuriazione di Empoli', L'Universo 6o (1980), 911-928; G. Ciampoltrini, 'Note sulla colonizzazione augustea nell'Etruria Settentrionale', Studi Classici e Orientali 31 (1981), 41-55.

40 See H.A. Orengo and J.M. Palet Martínez, 'Methodological insights into the study of centuriated field systems: a landscape archaeology perspective', Agri Centuriati: An International Journal of Landscape Archaeology 6 (2009), 171-185; T. de Haas, 'Managing the marshes: an integrated study of the centuriated landscape of the pontine plain', JASc: Reports 15 (2017), 470-481.

41 Preliminary report: D. Hagmann and V. Schreck, 'L'insediamento rurale romano di Molino San Vincenzo a Montespertoli', Milliarium 12 (2018), 42-59.

42 K. Freitag, 'The diversity of sites: results of the geophysical prospections 2016 and 2017 in the valleys of Pesa and Orme', in Schörner 2020, op. cit. (n. 33), 159-170. 


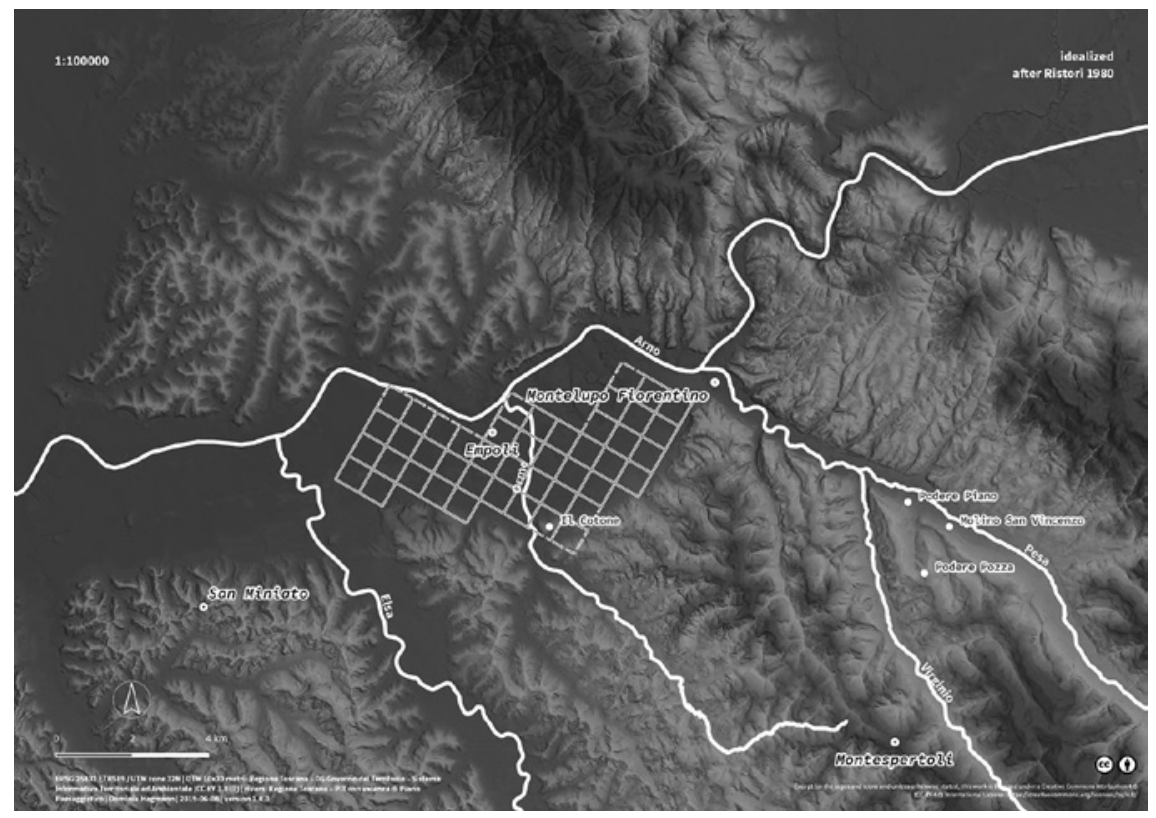

FIGURE 9.1 The research area with indication of the centuratio in the Arno plain near Empoli DESIGN D. HAGMANN (DEPARTMENT OF CLASSiCAL ARCHAEOLOGY, UNIVERSITY VIENNA) (AFTER RISTORI 1980)

everyday life: being largely unaffected by taphonomic deterioration, relatively well datable and available in large quantities, pottery represents the medium to study social diversity, especially in light of the possibility of pottery-analysis to follow a bottom-up approach for nearly all strata of society. ${ }^{43}$ That is, of course, especially important when we try to study non-elite rural inhabitants.

Based on the sherds found, activity and especially agricultural production is proven at Molino San Vincenzo already for the period from the 4th to the 2nd century BCE. Agricultural activity and human activity in general at Il Cotone started considerably later. Aside from a few sherds from the ist cent. BCE the largest part of the material stems from the Imperial time. ${ }^{44}$

Most interesting is a comparison of the assemblages found during the onsite surveys as we can detect a considerably distinct composition (fig. 9.2). The

43 For example: M. Pitts, 'Regional identities and the social use of ceramics', in J. Bruhn, B. Croxford and D. Grigoropoulos (eds.), TRAC 2004: Proceedings of the Fourteenth Annual Theoretical Roman Archaeology Conference, Durham 2004 (Oxford 2005), 50-64.

44 Pottery found at Il Cotone: H. Schörner, "The rural site of "Il Cotone": results of the on-sitesurvey 2016', in Schörner 2020, op. cit. (n. 33), 171-186. 


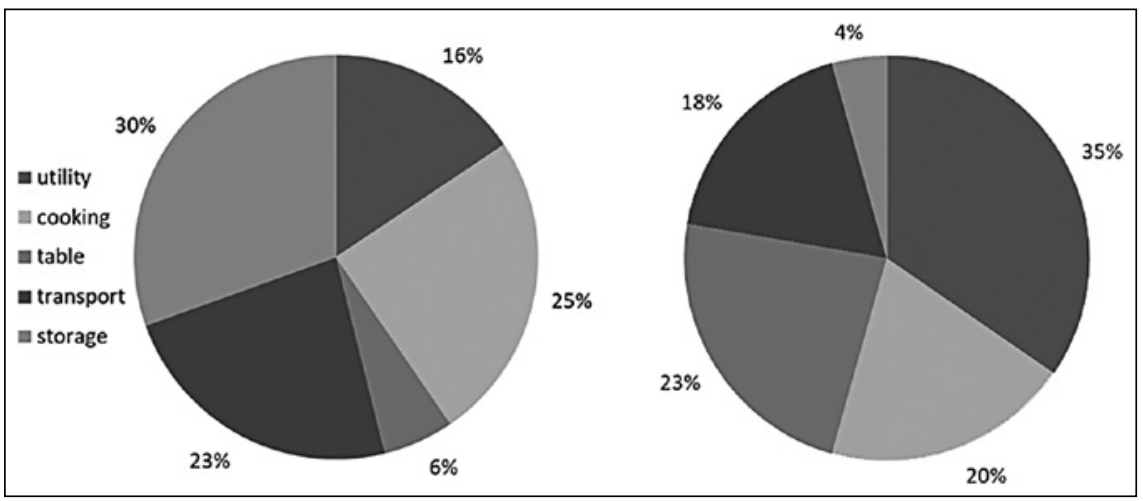

FIGURE 9.2 Quantitative distribution of pottery found at Molino San Vincenzo (left) and Il Cotone (right)

DESIGN H. SCHÖRNER (DEPARTMENT OF CLASSICAL ARCHAEOLOGY, UNIVERSITY VIENNA)

shares of utility pottery - a term used mostly for medium-sized vessel forms like dishes, bowls, large jugs for preparing, serving, or storing solid and liquid foodstuff in a fine-grained fabric - and of transport amphorae are roughly comparable. Marked differences relate to the shares of table wares - of which much more has been found in Cotone - and large vessels for storage (dolia), which are more common at Molino San Vincenzo. Both assemblages hint at a residential and also agricultural function of both places, but it can be presumed that life at Il Cotone was different to that of Molino San Vincenzo, particularly in terms of consumption: especially the much larger amount of table wares allows the supposition that the eating and drinking habits were more differentiated and elevated, even if the building found at Il Cotone was much smaller than that at Molino San Vincenzo. That impression is corroborated by the fact that Il Cotone yielded significantly higher percentages of imported Italian terra sigillata and other imported wares like African cooking wares or African table wares and imported amphorae, while Molino San Vincenzo has been provided mostly with locally or regionally produced wares, as has been proven by archaeometrical investigations.

It is probable that the position of Il Cotone in the centuriated hinterland of Empoli and - relating thereto - the ownership of the estate is the explanation for that marked difference to Molino San Vincenzo because the geographical distance is not a satisfying answer, especially as transport of goods to Molino San Vincenzo is easier to accomplish and cheaper due to the navigable waterways of Arno and Pesa. Therefore, a centuriatio was not only a means to rationally reorganize land, but it also had strong effects on consumption and social life in general which itself had implications how the landscape was seen and perceived. 
Landscape in Roman times has also been altered through changes in the nature of land use and agrarian exploitation. Here, especially archaeobotanical and zooarchaeologial studies are useful and promise more and deeper insights for the future. ${ }^{45}$ The Vienna Orrne and Pesa Valley Project has conducted palynological studies at Molino San Vincenzo. It greatly benefited from an approach in which pollen were extracted directly from archaeological layers.

The Roman samples of pollen from Molino San Vincenzo correlate with a phase of strong human activity characterized by the development of an agrarian system on the site consisting mainly of crop fields and grasslands. ${ }^{46}$ Diverse cereals were cultivated, represented in the spectra by hordeum, the avenatriticum group and secale. The high percentages of so-called local pastoral pollen indicators suggest that also pasture/breeding activities on pasturelands were of economic importance at the site.

Moreover, leguminosae, especially fabaceae, various clover species and true grasses (poaceae), are attested. These finds mostly consist of species that may have been cultivated for fodder. They have the propriety to enrich soils with nitrogen and have been traditionally employed in agriculture to rotate fields. Therefore, the cereal fields grown alternated with areas of lawn/pasturelands in a clearly human-shaped landscape. All this hints at an agricultural system which is called ley farming or convertible husbandry, the invention of which has been presumed only in late medieval or early modern Brabant, Flanders and Netherlands more than 1000 years later. ${ }^{47}$ Thus, the results of the Vienna

45 See, for instance, the transition in Rome through archaeozoological evidence: J. De Grossi Mazzorin and C. Minniti, 'Changes in lifestyle in ancient Rome (Italy) across the Iron Age/Roman transition: the evidence from animal remains', in U. Albarella et al. (eds.), The Oxford Handbook of Zooarchaeology (Oxford 2017), 127-146; transition in a provincial setting: S. Trixl, B. Steidl and J. Peters, 'Archaeology and zooarchaeology of the Late Iron Age: Roman transition in the province of Raetia (10o BC-10o AD)', European Journal of Archaeology 20 (2017), 431-450; archaeobotany: L. Sadori, A.M. Mercuri and M. Mariotti Lippi, 'Reconstructing past cultural landscape and Human impact using pollen and plant macroremains', Plant Biosystems - An International Journal Dealing with all Aspects of Plant Biology 144 (2010), 940-951; transition in a provincial setting: J. Wiethold, 'Late Celtic and early Roman plant remains from the oppidum of Bibracte, Mont Beuvray (Burgundy, France)', Vegetation History and Archaeobotany 5 (1996), 105-116.

46 Short summary of the results presented by: E. Rattighieri and A.M. Mercuri, 'Palynology from the Molino San Vincenzo Site in Tuscany: the plant landscape from the Roman layers', in Schörner 2020, op. cit. (n. 33), 99-112,

47 E. Kerridge, The Agricultural Revolution (London 1967); H. Kitsikopoulos, 'Convertible husbandry vs. regular common fields: a model on the relative efficiency of medieval field 


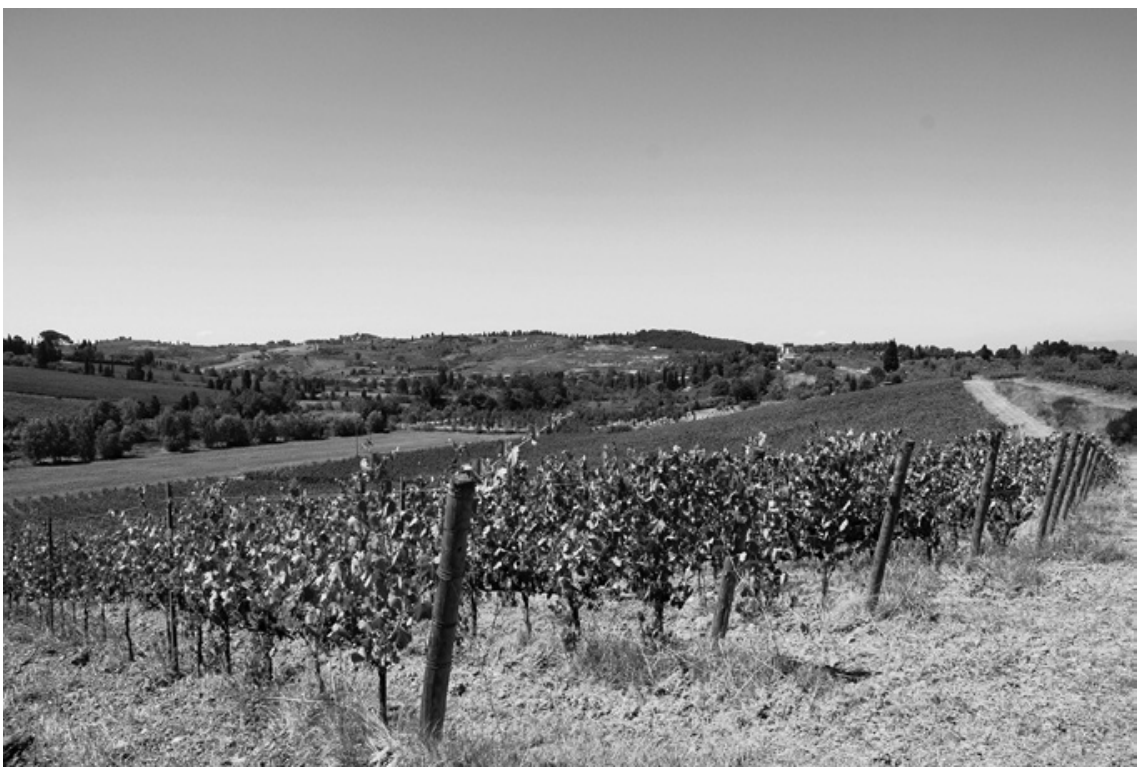

FIGURE 9.3 The (not so) timeless Tuscan landscape near Molino San Vincenzo (prov.

Florence)

PHOTOGRAPH G. SCHÖRNER (DEPARTMENT OF CLASSICAL ARCHAEOLOGY, UNIVERSITY VIENNA)

Orme and Pesa Valley Project have had a major impact on our knowledge of the vegetation history of Roman Etruria and by consequence on the appearance and conception of the landscape. ${ }^{48}$ Especially astonishing was that there were no indicators for growing vines and olives near Molino San Vincenzo. Consequently, the present-day landscape around Molino San Vincenzo, which is characterized by the alternation of vineyards and olive groves, differs greatly from the Roman landscape. Our idea or mental picture of a timeless Tuscan landscape (fig. 9.3) - how Tuscany has to look like - has to be abandoned.

systems', The Journal of Economic History 64 (2004), 462-499. Ley-farming in Roman times has been postulated by G. Kron based on written evidence: G. Kron, 'Roman leyfarming', JRA 13 (2000), 277-287.

48 Also in southern Tuscany, ley farming has been proven by pollen analysis of archaeological layers: K. Bowes et al., 'Peasant agricultural strategies in southern Tuscany: convertible agriculture and the importance of pasture', in T.C.A. de Haas and G.W. Tol (eds.), The Economic Integration of Roman Italy. Rural Communities in a Globalizing World (Leiden and Boston 2017), 170-199. 
The cultivation of vine was part of the Roman agrarian landscape in other parts of Etruria. Detailed evidence for the cultivation history in northern inland Etruria stems from Cetamura in Chianti at a distance of $35 \mathrm{kms}$ from Molino San Vincenzo where a rock-cut well has been excavated between 2011 and 2014. ${ }^{49}$ Seven chronological phases were detected, suggesting that it has been in use for around 370 years, from Late Etruscan I to Early Roman Empire II (300 BCE till 7o CE). Integrating the results of the biometric and molecular analyses of 454 grape pips found, it has been proposed that the sudden increase in pip size that occurred starting from around $200 \mathrm{BCE}$ was caused by a change in cultivation techniques rather than by the introduction of new varieties. Indeed, it is assumed that Etruscan viticulture did not include grafting or regular pruning. ${ }^{50}$ In contrast, the literary sources attest that viticulture in and around Rome was influenced by adopting innovative elements from Greek and/or Punic viticulture, like planting vines in regular rows, grafting and pruning. In consequence, it can be assumed that the increase in pip size was probably due to the introduction of new - Roman - management practices. Furthermore, the archaeological evidence at Cetamura indicates that in this period Roman amphorae for transporting wine (Dressel 1 and Lamboglia 2 types) replaced those from Massalia and southern Italy. ${ }^{51}$

Even if the primary motivation for the adoption of new techniques for growing vines was mostly economic, it is clear that it affected both the constructed and perceived landscape. The altered cultivation procedures profoundly changed the appearance of vineyards but we can go a step further: if we follow T. Ingold, it is the "practical operation, carried out by a skilled agent in an environment, as part of his or her normal business of life" - what he calls taskscape - what structures the perception of landscape. Therefore, the much higher work load and the greater need to take care for the vines would result in new ways to look at and understand the Chianti region at that time. ${ }^{52}$

The Cetamura example shows that the changed landscape in late Republican times started as an economic and cultural process and was independent of direct political or administrative inventions - in contrast to the centuriatio,

49 R. Aversano et al., 'Dating the beginning of the Roman viticultural model in the western Mediterranean: the case Study of Chianti (Central Italy)', PLOS one 12 (2017), 1-15 (accessed July 14 2020); the research was part of a larger field work project: N.T. de Grummond, Cetamura del Chianti (Austin 2020).

$5^{\circ} \quad$ Aversano et al. 2017, op. cit. (n. 48), 11.

$5^{1} \quad$ Aversano et al. 2017, op. cit. (n. 48), 11.

$5^{2}$ Ingold 1993, op. cit. (n. 18), 158. 
which, of course, follows historical decisions and governmental regulations. Furthermore, we have to think of the pronounced regional differences which leave the general picture very 'patchy', thereby perfectly fitting the concept of a landscape consisting of places.

\section{$6 \quad$ Some Final Theses}

Instead of a conclusion some theses shall be put forward: firstly there is of course an Impact of Empire on the rural environment, but the direction in which the development is headed is not determined from the outset. The changes in Roman times do not all go in one direction, to more productivity or to more well-being. In the case of Molino San Vincenzo we could observe a contrary development: In relative terms, elaborate table-wares such as bucchero, gray ware and vernice nera vessels were more numerous in the early phase of Molino San Vincenzo, while the simple, locally and regionally produced tableware starts to dominate from the 2nd century BCE onwards. ${ }^{53}$ The next settlement, Ponterotto, only $5 \mathrm{kms}$ upstream the Pesa, however, shows a marked increase in the quality of material culture in the same period of time $\mathrm{e}^{54}$ These results prove the very fragmented and localized developments which allows - in terms of landscape archaeology - for the conceptualisation of various meaningful places.

Secondly, in contrast to former studies I argue that this impact should not be called "romanization of landscape" because the term romanization assumes both a conscious policy and a fixed goal for landscape transformation, which was surely not the case. ${ }^{55}$ If we understand - following Knapp and Ashmore landscape not only as constructed but also as conceptualized and ideational, northern Tuscany may similarly be understood as a landscape of "Etruscan memory". ${ }^{6}$

Thirdly, it is to be questioned if there are any regions and landscapes, at least in Italy, that were not affected by Roman impact. That may be true for ownership structures (which are hard to investigate archaeologically), but it

53 V. Schreck, Die wirtschaftlichen Interaktionen im mittleren Arno-Tal am Beispiel der Keramik aus dem urbanen Zentrum von Empoli und den Siedlungen im Hinterland (PhD thesis, Vienna 2018).

54 L. Alderighi and A. Pittari, 'San Casciano in Val di Pesa (FI), l'insediamento rurale romano di Ponterotto', Notiziario della Soprintendenza per i Beni Archeologici della Toscana 9 (2014), 45-68.

55 See, for instance, Edmondson 1994, op. cit. (n. 35).

$56 \quad$ Knapp and Ashmore 1999, op. cit. (n. 7). 
seems to be ruled out that the agricultural techniques and the crops cultivated remained unaltered given the integration into the developed economy of Roman Italy since the ist cent. BCE at the latest. ${ }^{57}$ As all inhabitants of a particular region were affected by living in the Roman Empire, their perception of the landscape they lived and worked in or travelled through was influenced by that fact even if they focus on decidedly non-Roman features. That applies, however, to the opposite as well: Although there is an impact of the Roman Empire on landscapes, it has to be negated that there was ever a (single type of) Roman landscape per se..$^{58}$

$57 \quad$ See the essays in Haas and Tol 2017, op. cit (n. 47).

$5^{8}$ A classical case is Pausanias' description of Greece: J. Elsner, 'Pausanias: a Greek pilgrim in the Roman world', $P \& P 135$ (1992), 3-29; W. Hutton, Describing Greece: Landscape and Literature in the Periegesis of Pausanias (Cambridge 2005). 